\title{
Insulin resistance in Type 1 (insulin-dependent) diabetes: dependence on plasma insulin concentration
}

\author{
A.Pernet ${ }^{1,2}$, E. R. Trimble ${ }^{1,2}$, F. Kuntschen ${ }^{3}$, P. Damoiseaux ${ }^{2}$, J.-Ph. Assal ${ }^{2}$, C. Hahn ${ }^{3}$ and A. E. Renold ${ }^{1}$ \\ ${ }^{1}$ Institute of Clinical Biochemistry, University of Geneva, ${ }^{2}$ Diabetes Treatment and Teaching Unit, University Hospital of Geneva, and \\ ${ }^{3}$ Clinique de Genolier, Genolier, Switzerland
}

\begin{abstract}
Summary. Sensitivity to insulin in vivo was studied in six Type 1 diabetic patients without residual insulin secretion and without clinical insulin resistance, and in eight non-diabetic subjects, using the euglycaemic insulin clamp technique. Insulin was infused for four periods of $2 \mathbf{h}$ sequentially at $0.5,1.0$, 2.0 and $5.0 \mathrm{mU} \cdot \mathrm{kg}^{-1} \cdot \mathrm{min}^{-1}$; for each insulin infusion period the steady-state plasma free insulin levels were comparable in the diabetic and non-diabetic subjects. The mean \pm SEM plasma glucose concentration was $4.9 \pm 0.03 \mathrm{mmol} / \mathrm{l}$ in the diabetic subjects (coefficient of variation of plasma glucose values: $5.7 \pm 0.7 \%$ ) and $4.6 \pm 0.01 \mathrm{mmol} / 1$ in the control subjects (coefficient of variation: $5.1 \pm 0.6 \%$ ). Insulin-mediated glucose disposal was lower in the diabetic than in the non-diabetic
\end{abstract}

subjects at the two lower insulin infusion rates (mean \pm $\mathrm{SEM}=2.03 \pm 0.27$ versus $4.8 \pm 0.64 \mathrm{mg} \cdot \mathrm{kg}^{-1} \cdot \mathrm{min}^{-1}$ at the first insulin infusion rate, $p<0.01$, and $5.59 \pm 0.59$ versus $8.36 \pm 0.61 \mathrm{mg} \cdot \mathrm{kg}^{-1} \cdot \mathrm{min}^{-1}$ at the second insulin infusion rate, $p<0.01$ ). However, insulin-induced glucose uptake did not differ significantly between the two groups at the third and fourth rates of insulin infusion. These results show that impaired insulin sensitivity in Type 1 diabetes is dependent on insulin concentration.

Key words: Type 1 diabetes, glucose-controlled insulin infusion system, euglycaemic clamp, insulin dose response curve, free insulin, insulin antibodies.
Many studies have shown that a large percentage of Type 2 (non-insulin-dependent) diabetic subjects are insulin resistant [1-5]. The situation in Type 1 (insulin-dependent) diabetes has not been clarified fully. At least four studies have been carried out to investigate insulin sensitivity in Type 1 diabetes using a fixed insulin infusion rate to generate steady-state plasma insulin levels. In one, where diabetes was of recent onset, nine out of 12 subjects had insulin sensitivity similar to that of controls [6]. In the other three studies [7-9], where the subjects had long-standing diabetes, insulin-mediated glucose utilization was markedly reduced in diabetic subjects, both under hyperglycaemic and euglycaemic conditions $[8,9]$.

The present study was undertaken to define more precisely the responsiveness to insulin in vivo in longstanding Type 1 diabetes. Studies in vitro have shown in many pathological conditions that abnormal tissue response to insulin is not seen over the full insulin dose response curve, but may be restricted to a relatively narrow range of insulin concentrations. We have therefore studied insulin sensitivity in vivo over a wide range of insulin concentrations. The method used was that validated by Rizza et al. [10] where four insulin infusion rates (corresponding to four widely different plasma insulin concentrations) were applied sequentially in four 2-h periods using the euglycaemic clamp technique.

\section{Methods}

\section{Subjects}

Two groups were studied: (1) one group consisted of six male Type 1

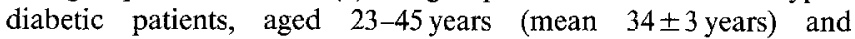
$97 \%-123 \%$ of ideal body weight (mean $108 \% \pm 4 \%$ ) [11]. All were without residual insulin secretion (no increase in plasma C-peptide concentration within $10 \mathrm{~min}$ following IV administration of $1 \mathrm{mg}$ of glucagon; Novo, Bagsvaerd, Denmark). The mean duration of diabetes was $19 \pm 4$ years (range $3.5-28$ years) and the mean total daily insulin dose was $43 \pm 5 \mathrm{U}$ (range 34-62 $\mathrm{U}$ ). None had evidence of renal or hepatic disease on routine laboratory examination and none was anaemic; (2) the other group consisted of eight healthy male volunteers, aged $25-45$ years (mean $30 \pm 2$ years) and $92 \%-117 \%$ of ideal body weight (mean $107 \% \pm 3 \%$ ) [11]. None had a family history of diabetes. All subjects were consuming a weight-maintaining diet containing at least $200 \mathrm{~g}$ of carbohydrate per day. None of the diabetic or control subjects was taking any medication other than insulin at the time of the study. There was no apparent difference in physical fitness between the two groups. In the diabetic patients, intermediate-acting insulin was stopped $48 \mathrm{~h}$ before the study to allow for the clearance of $\mathrm{SC}$ depots of insulin that could interfere with the test. In the period 
Table 1. Summary of clinical data in diabetic and control subjects

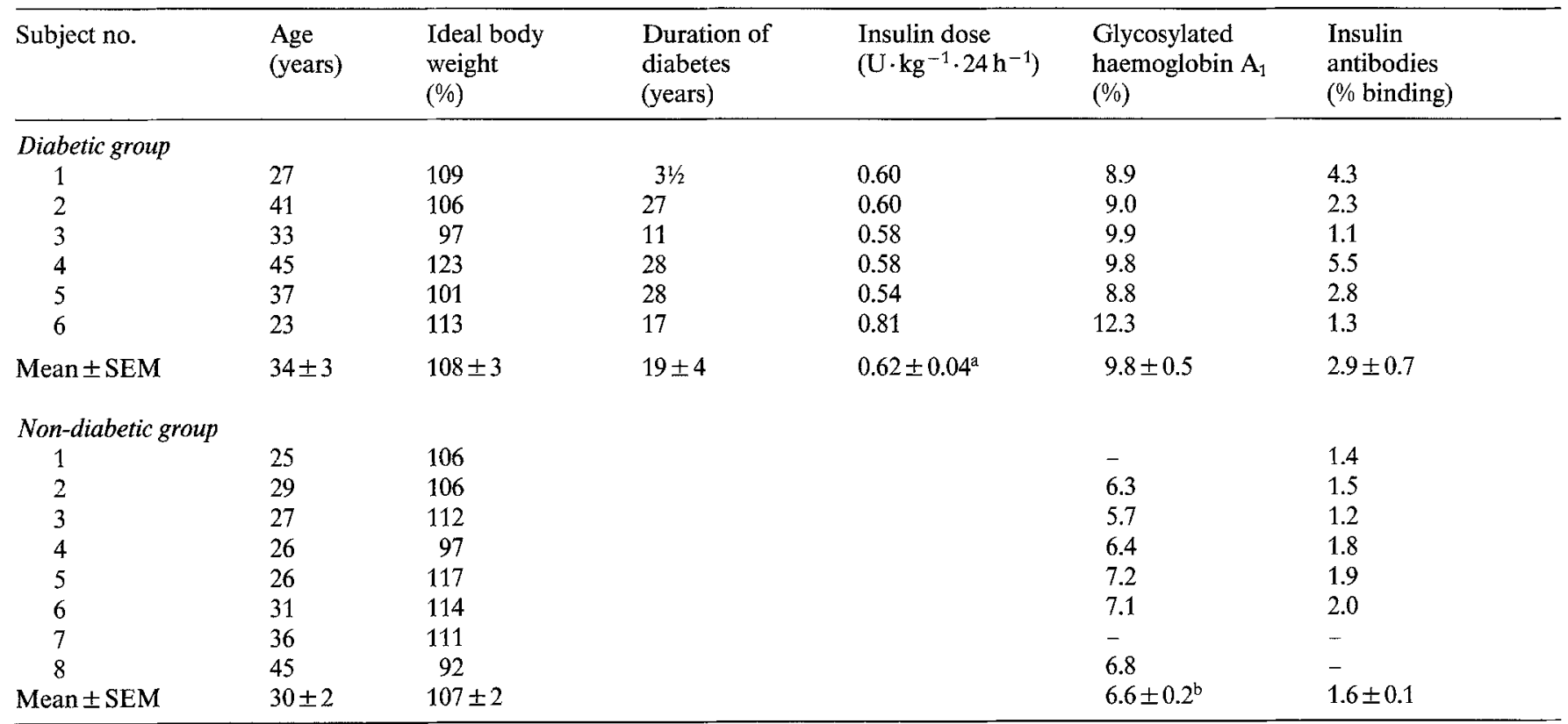

a Correspond to a daily insulin dose of $43 \pm 5 \mathrm{U}$ (range 34-62 $\mathrm{U}$ );

${ }^{b}$ highest accepted normal value for the laboratory $=9 \%$

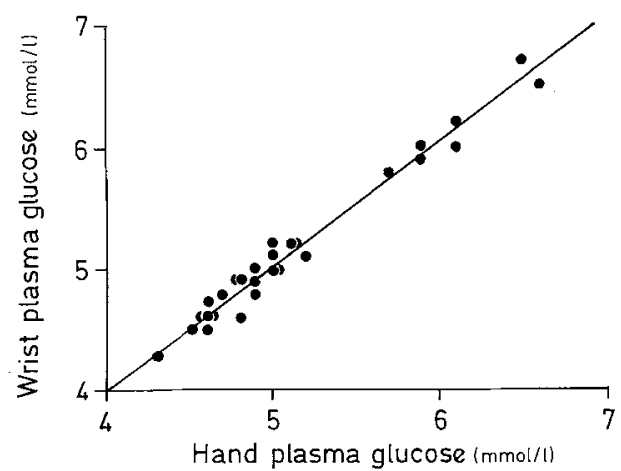

Fig. 1. Correlation of plasma glucose concentrations measured simultaneously at the wrist and hand in three diabetic subjects $(n=28$, $r=0.987)(\mathbf{O}=$ overlapping concentrations $)$

before the clamp, control of diabetes was achieved with SC injections of soluble insulin four times daily (Actrapid, Novo). One patient was treated with continuous SC insulin infusion. Another patient, being on a programme of long-acting insulin (Ultralente, Novo) plus soluble insulin (Actrapid) was put on continuous SC insulin infusion one week before the study. All studies were started at $07.00 \mathrm{~h}$ following a 10-h overnight fast. In all experiments, the subjects were placed in bed and maintained supine thereafter. The purpose, nature and potential risks of the study were carefully explained to all subjects who gave their consent orally. The protocol was reviewed and approved by the Ethical Committee of the University Hospital of Geneva.

\section{Insulin clamp study}

The diabetic subjects were admitted on the evening preceding the study, and were attached to a Biostator (Life Science Instruments, Miles Laboratories, Elkhart, Indiana, USA). A catheter was inserted under local anaesthesia in an antęcubital vein of the right arm for the administration of glucose and insulin; another catheter was placed in a forearm vein of the left arm for continuous blood withdrawal by the Biostator. The diabetic subjects were then stabilized overnight by the feedback-controlled insulin infusion. At $06.30 \mathrm{~h}$, a third catheter was inserted under local anaesthesia in a wrist vein of the left arm for intermittent blood sampling for determination of plasma glucose and insulin. Both the forearm vein (Biostator), and the wrist vein were maintained at $60^{\circ} \mathrm{C}$ in a thermo-regulated Plexiglas box to ensure arterialization of the venous blood [12].

The control subjects were admitted at $06.00 \mathrm{~h}$ on the day of the study, were cannulated as described above, and were attached to the Biostator for continuous monitoring of blood glucose.

Following the collection of three baseline blood samples, the subjects were infused with crystalline porcine insulin (Actrapid) at increasing rates of $0.5,1.0,2.0$ and $5.0 \mathrm{mU} \cdot \mathrm{kg}^{-1} \cdot \mathrm{min}^{-1}$ in four periods of $2 \mathrm{~h}$, using the insulin channel of the Biostator. A bolus of insulin was given before the insulin infusion, and before each subsequent increase in the insulin infusion rate, in order to raise plasma insulin levels acutely. The pulse injection was $4,5,10$ and $50 \mathrm{mU} / \mathrm{kg}$ before the first to fourth insulin infusion periods, respectively. Concurrent with the insulin infusion, variable amounts of glucose were infused as a $20 \%$ glucose solution with a precision pump (Vial Medical SE 400, La Forteresse, France) to clamp the plasma glucose level at the same concentration that had been present in the basal state (between 4.4 and $5.5 \mathrm{mmol} / \mathrm{l})$ in the diabetic and non-diabetic subjects. The necessary adjustments in the glucose infusion rate were made empirically, depending on changes in blood glucose concentrations observed during continuous glucose monitoring by the Biostator. Arterialized venous blood was sampled at 20-min intervals throughout the four insulin infusion periods for determination of plasma glucose and free insulin concentrations. Plasma glucose values were used to recalibrate the Biostator; this was done every $20 \mathrm{~min}$ using the pump-ratio adjustment knob.

In addition, four diabetic patients (Table 1, nos. 1,3,5 and 6) were readmitted for a non-sequential insulin clamp study. They were submitted to the same protocol as described above, and were again kept perfectly normoglycaemic during the night preceding the study by means of the Biostator. The insulin clamp study differed in that they were infused with insulin at the single rate of $1.0 \mathrm{mU} \cdot \mathrm{kg}^{-1} \cdot \mathrm{min}^{-1}$ for $4 \mathrm{~h}$. A bolus or $5 \mathrm{mU} / \mathrm{kg}$ was given before the insulin infusion. 


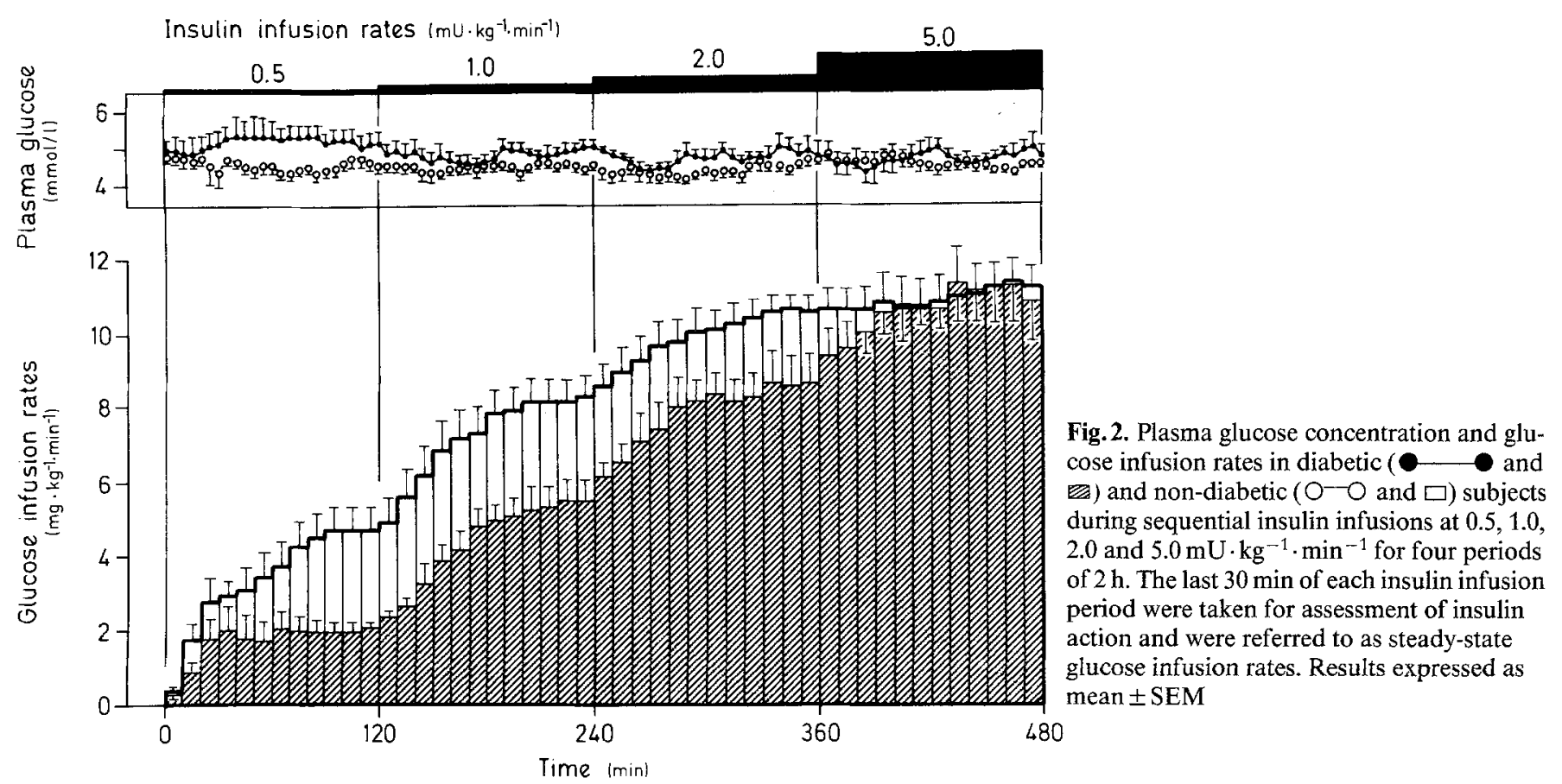

\section{Analytic procedures}

Plasma glucose was determined by the glucose-oxidase method (Beckman Instruments, Fullerton, California, USA). In all subjects, plasma was treated with polyethylene glycol (PEG) to remove insulin bound to antibody and then the plasma free insulin levels were assayed [13]. In the control subjects, the plasma free insulin concentrations, determined after the addition of PEG, averaged $106 \pm 6 \%$ of those determined directly by radioimmunoassay. Thus, complete recovery of free insulin was obtained after PEG treatment of plasma.

Insulin antibodies were measured as described by Kansal et al. [14] by treating the samples with acid charcoal before extraction of free and total insulin. The results were expressed as percentage binding of ${ }^{125} \mathrm{I}$-insulin to antibodies at a final plasma dilution of $1: 100$.

C-peptide was estimated using a Serono C-peptide assay kit (Serono Diagnostic, Coinsins, Switzerland) employing synthetic human Cpeptide and rabbit anti-human C-peptide antiserum [15]. The detection limit of the assay was $0.03 \mathrm{nmol} / \mathrm{l}$, and the cross-reactivity with proinsulin, $10 \%$

\section{Calculations}

The amount of glucose infused to maintain euglycaemia was calculated at 10-min intervals throughout the experiments, and was expressed as the amount infused per $\mathrm{kg}$ per min. Because equilibration between plasma insulin concentrations and insulin concentrations in the extravascular compartment is slow and takes at least $90 \mathrm{~min}$ [16], only the glucose infusion rates over the last $30 \mathrm{~min}$ of each insulin infusion period were used for the assessment of insulin action and were referred to as steady-state glucose infusion rates. Under these steady-state conditions, the amount of glucose infused to maintain euglycaemia is equivalent to insulin-induced enhancement of glucose uptake minus endogenous glucose production. Therefore the steady-state glucose infusion rate is a measure of the overall effect of insulin on total body glucose metabolism.

\section{Statistical analysis}

All data are presented as mean \pm SEM. Statistical comparisons between groups were performed by Student's unpaired t-test analysis (a $p$ value $<0.05$ was considered to be statistically significant).

\section{Results}

As the use of a wrist vein to sample arterialized blood had not been validated so far, we have compared the plasma glucose values obtained with blood taken simultaneously from a hand-vein and from a wrist-vein, both maintained at $60^{\circ} \mathrm{C}$. Twenty-eight paired determinations of plasma glucose were compared in three subjects (Fig.1). There was an excellent correlation between arterialized hand plasma glucose and wrist plasma glucose concentrations $(r=0.987)$.

\section{Euglycaemic insulin clamp}

The plasma glucose concentration in the diabetic patients was maintained throughout the experiment at $4.9 \pm 0.03 \mathrm{mmol} / 1$ and the mean coefficient of variation at 5-min intervals during the last $30 \mathrm{~min}$ of each insulin infusion period was $5.7 \pm 0.7 \%$ (Fig. 2). In the non-diabetic subjects, the plasma glucose concentration was clamped at $4.6 \pm 0.01 \mathrm{mmol} / 1$, with a mean coefficient of variation of $5.1 \pm 0.6 \%$ (Fig. 2).

Basal plasma free insulin concentrations were $7.4 \pm 1.3 \mathrm{mU} / 1$ in the non-diabetic versus $23.8 \pm 5.8$ $\mathrm{mU} / 1$ in the diabetic subjects $(p<0.01)$. In the non-diabetic group, the steady-state plasma free insulin concentrations were $27.3 \pm 2.8 \mathrm{mU} / 1$ during the first insulin infusion period, $71 \pm 9 \mathrm{mU} / 1$ during the second, $133 \pm$ $10 \mathrm{mU} / 1$ during the third, and $592 \pm 39 \mathrm{mU} / 1$ during the fourth (Fig.3). In the diabetic patients, the steady-state plasma free insulin concentrations were $21 \pm 5 \mathrm{mU} / 1$ during the first insulin infusion period, $82 \pm 14.4 \mathrm{mU} / \mathrm{I}$ during the second, $145 \pm 24.3 \mathrm{mU} / 1$ during the third, and $565 \pm 120 \mathrm{mU} / 1$ during the fourth (Fig. 3). There 


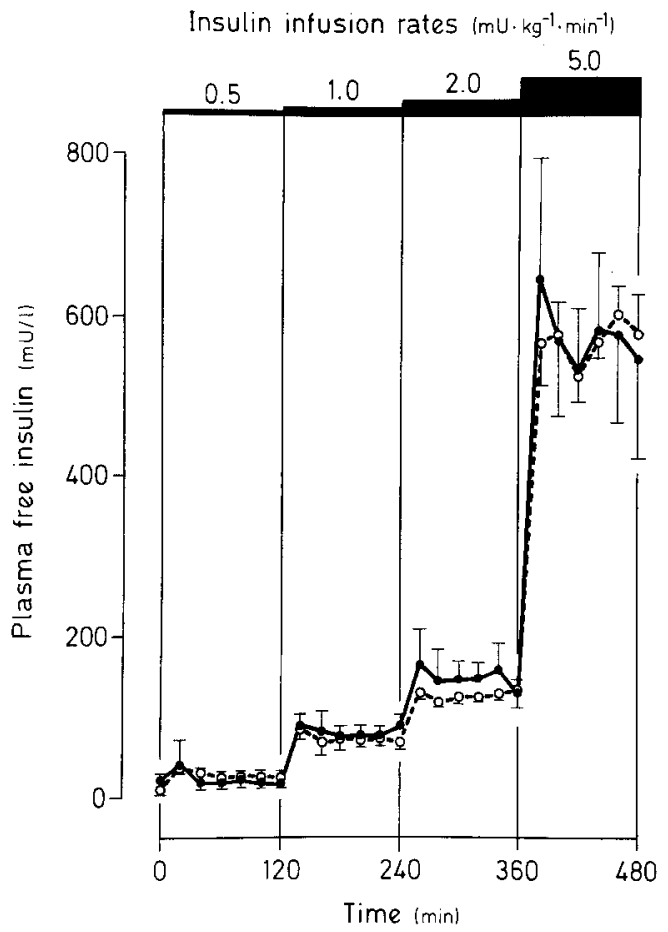

Fig.3. Plasma free insulin concentration in diabetic (-O) and non-diabetic subjects $\left(\mathrm{O}^{-} \mathrm{O}\right)$. Insulin infusion rates are represented at the top. Results expressed as mean \pm SEM

was no statistical difference between the plasma free insulin concentrations of the two groups at any time.

Plasma C-peptide concentrations were determined in six non-diabetic subjects during the first insulin infusion period (Fig. 4). Plasma C-peptide levels were decreased by $50 \%$ at $120 \mathrm{~min}$, demonstrating an adequate suppression of endogenous insulin secretion by insulin in these subjects.

The total amounts of glucose infused in the diabetic and control subjects are shown in Figure 2. The steadystate glucose infusion rate was $2.03 \pm 0.27 \mathrm{mg} \cdot \mathrm{kg}^{-1}$. $\min ^{-1}$ (range $1.08-2.56 \mathrm{mg} \cdot \mathrm{kg}^{-1} \cdot \mathrm{min}^{-1}$ ) in the diabetic versus $4.8 \pm 0.64 \mathrm{mg} \cdot \mathrm{kg} \cdot{ }^{-1} \cdot \mathrm{min}^{-1}$ (range $2.64-7.97$ $\mathrm{mg} \cdot \mathrm{kg}^{-1} \cdot \mathrm{min}^{-1}$ ) in the non-diabetic subjects during the first infusion period $(p<0.01)$ and $5.59 \pm$ $0.59 \mathrm{mg} \cdot \mathrm{kg}^{-1} \cdot \mathrm{min}^{-1}$ (range $3.47-7.20 \mathrm{mg} \cdot \mathrm{kg}^{-1}$. $\min ^{-1}$ ) versus $8.36 \pm 0.61 \mathrm{mg} \cdot \mathrm{kg}^{-1} \cdot \mathrm{min}^{-1}$ (range $6.30-11.3 \mathrm{mg} \cdot \mathrm{kg}^{-1} \cdot \mathrm{min}^{-1}$ ) respectively, during the second infusion period ( $p<0.01$; Fig. 5). The steady-state glucose infusion rates did not differ statistically between the two groups during the third and fourth infusion period corresponding to insulin infusion rates of 2.0 and $5.0 \mathrm{mU} \cdot \mathrm{kg}^{-1} \cdot \mathrm{min}^{-1}$ (Fig. 5).

When insulin was infused in four diabetic subjects at the single rate of $1.0 \mathrm{mU} \cdot \mathrm{kg}^{-1} \cdot \mathrm{min}^{-1}$ for $4 \mathrm{~h}$, the glucose requirements during hour 4 were $5.65 \pm 0.7 \mathrm{mg}$. $\mathrm{kg}^{-1} \cdot \mathrm{min}^{-1}$ (range $3.62-6.74 \mathrm{mg} \cdot \mathrm{kg}^{-1} \cdot \mathrm{min}^{-1}$ ) this value is similar to the steady-state glucose infusion rate

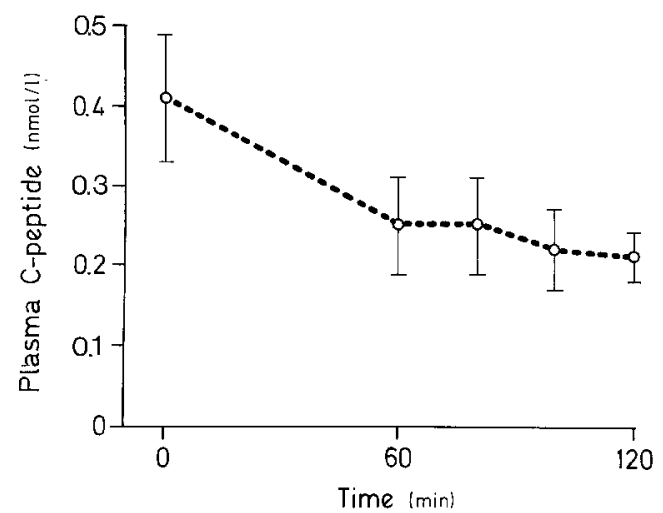

Fig.4. Plasma C-peptide concentrations in six control subjects during the first insulin infusion period. Results expressed as mean \pm SEM

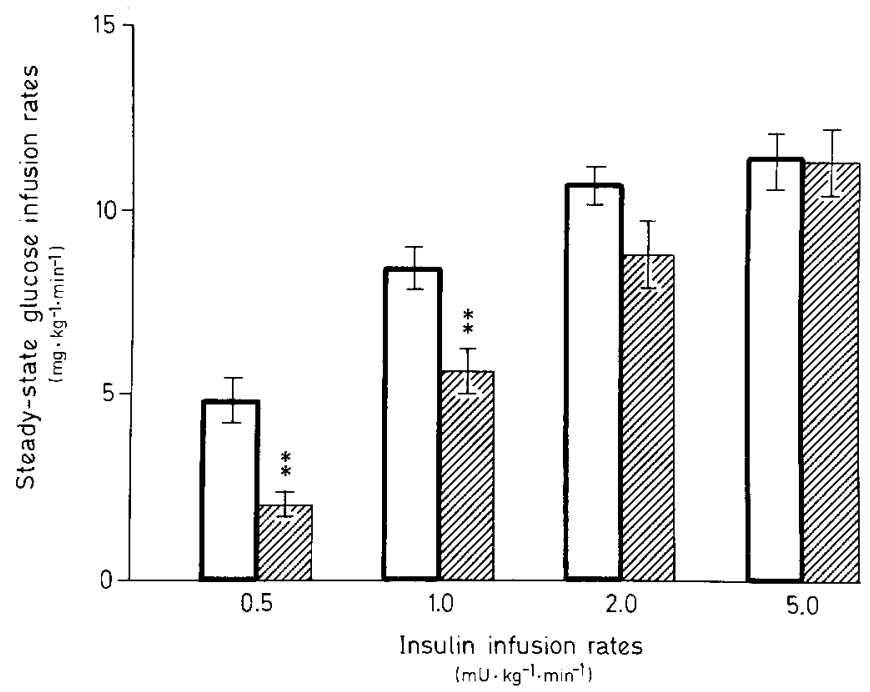

Fig. 5. Steady-state glucose infusion rates in diabetic (W) and control subjects $(\square)$ for each insulin infusion period. Results expressed as mean \pm SEM. $* * 00.01$

obtained with the same rate of insulin infusion in the sequential insulin clamp study $\left(5.59 \pm 0.59 \mathrm{mg} \cdot \mathrm{kg}^{-1}\right.$. $\min ^{-1}$, range $\left.3.47-7.2 \mathrm{mg} \cdot \mathrm{kg}^{-1} \cdot \mathrm{min}^{-1}\right)$.

\section{Insulin antibodies}

The binding of ${ }^{125}$ I-insulin was $1.6 \pm 0.1 \%$ (range $1.2-2 \%$ ) in non-diabetic subjects and $2.9 \pm 0.7 \%$ (range $1.1-5.5 \%$ ) in diabetic subjects (Table 1). Only two diabetic subjects (nos. 1 and 4 ) showed ${ }^{125}$ I-insulin binding in excess of $4 \%$. The insulin binding in the plasma of these two subjects was not associated with evidence of diminished insulin action at the tissue level. Thus, the glucose infusion requirements to maintain euglycaemia were 1.81 and $2.21 \mathrm{mg} \cdot \mathrm{kg}^{-1} \cdot \mathrm{min}^{-1}$ during the first insulin infusion period and 5.87 and $5.27 \mathrm{mg} \cdot \mathrm{kg}^{-1} \cdot \mathrm{min}^{-1}$ during the second infusion period. In neither case were these the lowest infusion rates for these two periods. 


\section{Discussion}

The present study shows that Type 1 diabetic subjects with long-standing diabetes are resistant to insulin at concentrations within the physiological range (corresponding to the two lower insulin infusion rates), while being equally sensitive as non-diabetic subjects at supraphysiological insulin levels. The methodology used in our experiments (sequential insulin infusion combined with euglycaemic clamping) has been validated by Rizza et al. in normal subjects [10]. However, there are no such data available for Type 1 diabetic subjects in whom insulin kinetics may be different. We have therefore assessed four diabetic patients with a single insulin infusion rate $\left(1 \mathrm{mU} \cdot \mathrm{kg}^{-1} \cdot \mathrm{min}^{-1}\right)$ for $4 \mathrm{~h}$ and found that glucose utilisation rates under these conditions were similar to those obtained at the same insulin infusion rate during the sequential insulin clamp study. This indicates that it is possible to use a sequential insulin infusion for assessing insulin sensitivity in Type 1 diabetic subjects, at least in those with relatively low insulin antibody titres. DeFronzo et al. also found insulin resistance in Type 1 diabetic patients of long duration at plasma free insulin levels which were comparable to those measured during the second insulin infusion period of our study [8].

In a recent report, Proietto et al. showed that glucose utilisation was markedly reduced in poorly-controlled Type 1 diabetic subjects with long-standing diabetes but, in contrast to our findings, this defect could not be corrected by hyperinsulinaemia [9]. Two points can be raised in view of this apparent discrepancy between our two studies. The first deals with mean circulating plasma free insulin concentrations which were much lower in the Australian study $(247 \mathrm{mU} / 1)$ than in our study $(565 \mathrm{mU} / 1)$ for the same insulin infusion rate of $5 \mathrm{mU}$. $\mathrm{kg}^{-1} \cdot \mathrm{min}^{-1}$. Thus, the Australian diabetic patients may have had significant anti-insulin antibody titres which could well explain the reduced response to insulin seen at the high insulin infusion rate. By contrast, the diabetic patients investigated in our study had low antibody titres to insulin, and their plasma free insulin levels during infusion were similar to those of non-diabetic subjects at each insulin infusion rate employed. The second point deals with the quality of glycaemic control preceding the clamp, which was also different in the two studies. The Australian diabetic patients were chosen because of poor metabolic control and a mean glycosylated haemoglobin $\mathrm{A}_{1 \mathrm{c}}$ level of $13.7 \%$. It is known that sensitivity to insulin can change with the degree of metabolic control [17, 18]. Ginsberg [17] showed that insulin resistance was very high during ketoacidosis. The subjects of our study did not have any recent episodes of ketoacidosis (within 12 months) and, in addition, the good quality of their glycaemic control was shown by the fact that their mean glycosylated haemoglobin level was only just above the normal limit for our laboratory $(9 \%)$. Moreover, during the hours before the clamp started, the patients were maintained in normoglycaemia by means of the Biostator. This ensured that the baseline glycaemia matched that of the non-diabetic subjects. If glycaemic control is important in the precise assessment of insulin resistance, this study avoids the possible bias of elevated blood glucose. This is not the case in all recent studies. However, one can question the possible effects of overnight intravenous insulin administration on the measurement of insulin sensitivity the following day. Could this have caused down-regulation of insulin receptors? We do not think so because the amount of insulin given during the night preceding the clamp was, on average, less than the regular evening dose of insulin for these subjects $(1.0 \pm 0.09 \mathrm{U} / \mathrm{h}$ from 23.00 to $07.00 \mathrm{~h}$, while the average evening insulin dose was $15.2 \pm 3.9 \mathrm{U}$ ).

It has been shown that hepatic glucose production can be inhibited easily by insulin both in Type 1 diabetes $[8,9,19,20]$ and in non-diabetic subjects $[8,10,20]$ and that plasma insulin levels of approximately $50 \mathrm{mU} / 1$ cause a $70 \%$ or more suppression of hepatic glucose production [8-10]. Thus, in our study, hepatic glucose production should have been suppressed to a major extent at the second, third and fourth insulin infusion rates both in diabetic and non-diabetic subjects, and glucose infusion rates during these periods could be equated with glucose disposal rates.

The cause of insulin resistance seen at the two lower insulin concentrations remains unexplained. Reduced insulin-mediated glucose metabolism may have been due to reduced insulin binding, impaired glucose transport, or post-receptor impairment of certain metabolic pathways. Insulin binding to circulating blood cells has been reported to be unchanged or elevated in Type 1 diabetes [21-23]. More recently, however, there has been an interesting report in which insulin binding to circulating blood cells has been compared with binding to adipocytes in Type 1 diabetic subjects [24]. It was shown that, while insulin binding to both erythrocytes and monocytes may be similar for Type 1 diabetic and non-diabetic subjects, insulin binding to adipocytes is reduced in Type 1 diabetes. Thus, it is possible that the decreased glucose disposal observed at the lower insulin infusion rates in this study could have been due to decreased insulin binding to fixed tissues, such as adipose tissue and, more importantly, muscle. Further support for this idea comes from the fact that at high plasma insulin levels glucose disposal rates were similar for diabetic and control subjects. However, some impairment of post-receptor metabolic pathways cannot be entirely excluded on the basis of our in vivo data.

In conclusion, at physiological insulin concentrations, Type 1 diabetic patients were found to be resistant to insulin when compared with non-diabetic subjects. In contrast, high, supraphysiological levels of insulin had a similar effect on glucose disposal in Type 1 diabetic and non-diabetic subjects. 
Acknowledgements. The authors acknowledge with gratitude the cooperation of the medical and nursing staff of the Diabetes Treatment and Teaching Unit, Hôpital Cantonal Universitaire, Geneva, and the expert technical assistance of Ms. T.Cuche and Ms. C. Brenner. We thank Dr. L. Vadas for measurement of plasma C-peptide levels, and Dr. N. Mensi for measurement of glycosylated haemoglobin levels. The project was supported by grant no.3.246-0.82SR of the Swiss National Science Foundation.

\section{References}

1. Himsworth HP, Kerr PB (1939) Insulin sensitive and insulin insensitive types of diabetes mellitus. Clin Sci 4: 119-152.

2. Olefsky JM, Reaven GM (1977) Insulin binding in diabetes. Relationships with plasma insulin levels and insulin sensitivity. Diabetes $26: 680-688$

3. Fajans SS, Cloutier MC, Crowther RL (1978) Clinical etiologic heterogeneity of idiopathic diabetes mellitus. Diabetes 27: 1112-1125

4. Efendic S, Wajngot A, Cerasi E, Luft P (1980) Insulin release, insulin sensitivity and glucose intolerance. Proc Natl Acad Sci USA 77: 7425-7429

5. Kolterman OG, Gray RS, Griffin S, Burstein P, Insel J, Scarlett JM, Olefsky JM (1981) Receptor and post-receptor defects contribute to the insulin resistance in non-insulin dependent diabetes mellitus. J Clin Invest 68: 957-969

6. Ginsberg HN (1977) Investigation of insulin sensitivity in treated subjects with ketosis-prone diabetes mellitus. Diabetes 26: $278-283$

7. Harano Y, Ohgaku S, Kosugi K, Yasuda H, Nakano T, Kobayashi M, Hidaka H, Izumi K, Kashiwagi A, Shigeta Y (1981) Clinical significance of altered insulin sensitivity in diabetes mellitus assessed by glucose, insulin, and somatostatin infusion. J Clin Endocrinol Metab 52: 982-987

8. DeFronzo RA, Hendler R, Simonson D (1982) Insulin resistance is a prominent feature of insulin-dependent diabetes. Diabetes 31 : 795-801

9. Proietto J, Nankervis A, Aitken P, Caruso G, Alford F (1983) Glucose utilization in Type 1 (insulin-dependent) diabetes: evidence for a defect not reversible by acute elevations of insulin. Diabetologia 25:331-335

10. Rizza RA, Mandarino LJ, Gerich JE (1981) Dose-response characteristics for effects of insulin on production and utilization of glucose in man. Am J Physiol 240: E630-E639

11. Metropolitan Life Insurance Tables (1959) Statist Bull Metrop Life Insur Co. 40

12. McGuire EAH, Helderman JH, Tobin JD, Andres R, Berman M (1976) Effects of arterial versus venous sampling. An analysis of glucose kinetics in man. J Appl Physiol 41: 565-573
13. Nakagawa $S$, Nakayama $H$, Sasaki T, Yoshimo $K$, Ying Yu $Y$, Shinozaki K, Aoki S, Mashimo K (1973) A simple method for the determination of serum free insulin levels in insulin-treated patients. Diabetes 22: 590-600

14. Kansal PC, Bandisode MS, Boshell BR (1979) Determination of insulin antibodies. Horm Metab Res 11: 187-189

15. Kuzuya T, Matsuda A, Saito T, Yoshida S (1976) Human C-peptide immunoreactivity (CPR) in blood and urine. Evaluation of a radioimmunoassay method and its clinical applications. Diabetologia 12: 511-518

16. Sherwin RS, Kramer K, Tobin J, Insel P, Liljenquist J, Berman M, Andres, R (1974) A model of the kinetics of insulin in man. J Clin Invest 53: 1481-1492

17. Ginsberg HN (1977) Investigation of insulin resistance during diabetic ketoacidosis: role of counterregulatory substances and effect of insulin therapy. Metabolism 26: 1135-1146

18. Valenta LJ, Elias AN, Grossman M, Tanner SM, Friis R (1982) A new test of peripheral insulin sensitivity in vivo using artifical beta cell. Life Sci 30: 867-873

19. Bearn AG, Billing BH, Sherlock S (1951) Hepatic glucose output and insulin sensitivity in diabetes mellitus. Lancet $2: 698-700$

20. Sacca L, Sherwin RS, Hendler R, Felig P (1979) Influence of continuous physiologic hyperinsulinemia on glucose kinetics and counterregulatory hormones in normal and diabetic humans. J Clin Invest 63: 849-857

21. Pedersen O, Beck-Nielsen $H$, Heding $L$ (1978) Insulin receptors on monocytes from patients with ketosis-prone diabetes mellitus. Diabetes 27: 1098-1104

22. Kappy MS, Plotnick LP, Findlay JC, Kayne RD (1980) Erythrocyte insulin binding in insulin-dependent diabetes mellitus: lack of relationship to duration and control of diabetes in children and adolescents. Pediatrics 66 : $385-390$

23. Fantus G, Ryan J, Gorden $P(1981)$ The insulin receptor in insulindependent diabetes mellitus: an in vivo and in vitro study. Metabolism 30: 510-517

24. Pedersen O, Hjøllund $E$ (1982) Insulin receptor binding to fat and blood cells and insulin action in fat cells from insulin-dependent diabetics. Diabetes 31: 706-715.

Received: June 1983

and in revised form: 28 November 83

Dr. A. Pernet

Institut de biochimie clinique

Sentier de la Roseraie

CH-1205 Geneva

Switzerland 